Published in final edited form as:

Curr Opin Virol. 2018 February ; 28: 7-11. doi:10.1016/j.coviro.2017.09.004.

\title{
Transmission of henipaviruses
}

\author{
Sarah Weatherman, Heinz Feldmann, and Emmie de Wit ${ }^{*}$ \\ Laboratory of Virology, National Institute of Allergy and Infectious Diseases, National Institutes of \\ Health, Hamilton, MT, United States of America
}

\begin{abstract}
The genus Henipavirus has expanded rapidly in geographic range, number of species, and host range. Hendra and Nipah virus are two henipaviruses known to cause severe disease in humans with a high case-fatality rate. Pteropid spp. bats are the natural reservoir of Hendra and Nipah virus. From these bats, virus can be transmitted to an amplifying host, horses and pigs, and from these hosts to humans, or the virus can be transmitted directly to humans. Although the main route of shedding varies between host species, close contact is required for transmission in all hosts. Understanding the transmission routes of Hendra and Nipah virus in their respective hosts is essential for devising strategies to block zoonotic transmission.
\end{abstract}

\section{Introduction}

In September 1994, a small outbreak of respiratory disease occurred in horses in a stable in Hendra, Australia. Shortly after the death of the index horse, a stable hand and horse trainer who had been in close contact with the animal developed an influenza-like illness, that resolved in the stable hand, but progressed to fatal acute respiratory distress syndrome in the horse trainer. A previously unknown paramyxovirus, later named Hendra virus, was isolated from the horses and the fatal human case (1). An extensive search soon identified Pteropid species bats as the natural reservoir of Hendra virus $(2,3)$, from which it was transmitted to horses. To date, around 100 cases of Hendra virus infection in horses, and seven human cases with four fatalities have been identified (4); infection of dogs with Hendra virus after close contact with sick horses has also been detected, but it is currently not clear whether dogs play a role in transmission of Hendra virus (5).

In 1998, a concurrent infectious disease outbreak occurred in pigs with respiratory disease and humans with neurological disease in Kampung Sungai Nipah, Malaysia. A common causative agent was suspected since the majority of human cases had direct contact with affected pigs. The disease spread with the movement of infected pigs through Malaysia and

*Corresponding author: Emmie de Wit; 903 South $4{ }^{\text {th }}$ Street, Hamilton, MT 59840, USA; emmie.dewit@nih.gov; phone: +1-406-375-7490; fax +1-406-375-9620.

Conflict of interest

The authors have no conflict of interest to declare.

Publisher's Disclaimer: This is a PDF file of an unedited manuscript that has been accepted for publication. As a service to our customers we are providing this early version of the manuscript. The manuscript will undergo copyediting, typesetting, and review of the resulting proof before it is published in its final citable form. Please note that during the production process errors may be discovered which could affect the content, and all legal disclaimers that apply to the journal pertain. 
into Singapore, resulting in 276 human cases with 106 fatalities and the culling of more than $1,000,000$ pigs $(6,7)$. The causative agent, named Nipah virus, was isolated from cerebrospinal fluid of a human fatal case and shown to be closely related to Hendra virus. Although no further cases of Nipah virus infection were identified in Malaysia, Nipah virus caused outbreaks in India in 2001 and 2007 (8, 9), and multiple outbreaks of Nipah virus as well as isolated cases have been identified in Bangladesh since 2001 (10,11). In 2014, a small outbreak of encephalitis in two villages in the Philippines was traced to the slaughtering and consumption of horses with neurological disease. Serologic evidence indicates that horses and humans were infected with Nipah virus or a Nipah-like virus (12). Like Hendra virus, Nipah virus originates from Pteropus spp. fruit bats (13). Zoonotic transmission of Hendra virus in Australia and Nipah virus in Malaysia and the Philippines occurred through an amplifying host, pigs and horses, whereas zoonotic transmission in Bangladesh is thought to occur directly from bats to humans mainly through the consumption of raw date palm sap contaminated with Nipah virus by fruit bats.

Besides Hendra and Nipah virus, the Henipavirus genus currently contains three additional species: Cedar virus, Ghanaian bat virus and Mojiang virus. Cedar virus was isolated from urine samples collected from a flying fox colony in Australia. Experimental inoculation of ferrets and guinea pigs with Cedar virus did not result in clinical disease and there is no evidence that Cedar virus is pathogenic in humans (14). Ghanaian bat virus and Mojiang virus species were established based on detection of viral RNA rather than isolation of a novel virus $(15,16)$. There is no direct evidence that either virus causes disease in humans; however, Mojiang virus RNA was isolated from rectal swabs from rats ( $R$. flavipectus) caught in an abandoned mine where three workers may have acquired fatal pneumonia of unknown origin six months earlier (16). Moreover, serologic evidence of Ghanaian bat virus, or a related Henipavirus, in pigs in Africa indicates a potential for zoonotic transmission (17). Indeed, serological evidence of Henipavirus infection has been found in humans in Cameroon (18).

In this review, we summarize the current state of knowledge on the intraspecies transmission of henipaviruses. Since there is no information available on the transmission of Cedar virus, Ghanaian bat virus or Mojiang virus, the review focuses on transmission of Hendra virus and Nipah virus in Pteropid spp. bats, horses, pigs and humans.

\section{Bat- to-bat transmission}

Pteropid spp. bats or flying foxes are the reservoir hosts of Hendra and Nipah virus. These bats have a wide geographic range and evidence of Henipavirus infection has been found in bats from South East Asia, Africa, South and Central America (reviewed in (19, 20)). Little is known about the effect of Henipavirus infection on naturally infected bats; however, experimentally infected Pteropid spp. bats do not show signs of disease and limited pathological changes (21-24). During infection, virus is shed mainly in urine but can also be detected in throat and rectal swabs $(21-23,25)$. Although studies have found associations between environmental factors or reproductive status and shedding of Hendra and Nipah virus in flying foxes, these factors seem to be dependent on the location and virus studied (25-28). Vertical transmission has been shown to occur in pregnant bats experimentally 
infected with Hendra virus (23); however, no Hendra virus RNA was detected in fetal tissue from naturally infected bats (29). Contact transmission was not observed from $P$. poliocephalus bats inoculated with Hendra virus to naive animals, which may be explained by the fact that no virus shedding was detected from the inoculated bats (24). Regardless, bat-to-bat transmission of Nipah and Hendra virus is thought to occur through direct contact, with transmission being aided by the high density of bats in roosts and the use of urine in grooming (22).

\section{Horse-to-horse transmission}

Since the Henipavirus outbreak in horses in the Philippines was retrospectively diagnosed this section focuses exclusively on Hendra virus infection and transmission in horses.

Natural infection of horses with Hendra virus results in depression and fever, progressing to neurological and respiratory disease, with a copious frothy nasal discharge in the end stage of disease (30). The case-fatality rate in horses is around 90\% (4). Few experimental infections of horses have been performed due to the difficulty of working with large animals in BSL4 containment. Disease signs in experimentally infected horses largely mimic those in naturally infected animals; however, horses in experimental infection studies meet euthanasia criteria and are taken out of the experiment before the development of severe respiratory and neurological disease and the typical frothy nasal discharge $(1,24,31)$. The main histological lesions in horses experimentally infected with Hendra virus were interstitial pneumonia and systemic vasculitis $(24,31,32)$. In experimentally infected horses, shedding of viral RNA was detected in urine, oral and nasal swabs, with shedding being highest and of longest duration in nasal swabs $(24,31)$. Viral RNA can also be detected on environmental swabs collected in stalls where naturally infected horses were housed (33). Viral shedding has been shown to occur before the onset of disease signs in experimentally infected horses, suggesting that asymptomatic horses could spread the infection (31). Housing of experimentally infected and naïve horses in adjacent stalls did not result in transmission of Hendra virus to the naïve animals (24); however, the lack of transmission may have been due to the lack of the frothy nasal discharge that was proposed to play an important role in transmission between horses and zoonotic transmission (31). Taken together, the data on natural as well as experimentally infected horses indicate that the most likely route of transmission of Hendra virus between horses is through very close contact with infected horses in the end stage of disease, when virus shedding is at its' peak. Additionally, extensive handling of horses by humans without adequate measures to prevent cross-contamination could contribute to the spread of Hendra virus among horses (33).

\section{Pig-to-pig transmission}

Nipah virus disease manifests in naturally infected pigs as an acute febrile illness with respiratory signs such as nasal discharge, a barking cough and labored breathing, as well as neurological signs (7). The severity of Nipah virus disease in naturally infected pigs depends on the age of the animals. The mortality rate in pigs in Malaysia was high ( 40\%) in suckling pigs, but low (1-5\%) in pigs over 4 weeks of age (7). 
Disease signs in pigs inoculated experimentally with Nipah virus range from subclinical to clinical, with respiratory and neurological signs. Histologically, symptomatic pigs presented with interstitial pneumonia, non-suppurative meningitis, and systemic vasculitis $(34,35)$, lesions that were also typically observed in naturally infected pigs in Malaysia (7). Virus shedding was detected in the nose and throat of experimentally infected animals, with the highest amount of virus being detected in the nose. Importantly, virus shedding was observed in clinically and subclinically infected pigs $(34,35)$. Transmission of virus from experimentally infected animals to naïve pen-mates was observed several days after inoculated animals started to shed virus (34). Based on epidemiological data from the Nipah virus outbreak in Malaysia and transmission in experimentally-infected animals, transmission of Nipah virus between pigs in close contact is rapid and efficient, most likely occurs through direct contact with nasal secretions, and clinically as well as subclinically infected animals may transmit the virus $(7,34)$.

\section{Human-to-human transmission}

In humans, Hendra and Nipah virus cause an acute febrile illness with respiratory symptoms. During acute disease, Nipah virus is shed in urine as well as respiratory secretions from the mouth and nose $(9,36)$. Disease often progresses to acute respiratory distress syndrome and severe neurological disease with long-term consequences and relapses $(37,38)$. The casefatality rate of both virus infections is very high. Histological lesions in fatal cases of Hendra and Nipah virus infection included interstitial pneumonia, systemic vasculitis and meningitis $(1,39)$.

There is no evidence that Hendra virus is transmitted between humans. In contrast, humanto-human transmission of Nipah virus has significantly contributed to the number of Nipah virus cases in India, Bangladesh and the Philippines. In the Nipah virus outbreak in 2001 in India, $75 \%$ of cases were acquired through human-to-human transmission (9). Epidemiological analysis of Nipah virus outbreaks in Bangladesh from 2001-2007 showed that $50 \%$ of patients contracted the virus through human-to-human transmission; however, only $7 \%$ of Nipah virus patients transmitted the virus (40). Patients with respiratory disease and coughing were more likely to transmit Nipah virus; fatal cases were more likely to transmit than non-fatal cases (40). Nipah virus transmission from deceased patients to people who came in contact with the body after death has also been described $(41,42)$. Nosocomial transmission of Nipah virus was rare in Malaysia and Bangladesh $(43,44)$, but the main source of Nipah virus cases in Siliguri, India, where 25 out of 66 Nipah virus infections were in hospital staff (9). Despite the risk for transmission through aerosols or respiratory droplets with a virus that causes infection of the respiratory tract, epidemiological studies have shown that close contact is required for human-to-human transmission of Nipah virus $(41,45-48)$. These data were confirmed by experimental transmission studies in the hamster model of Nipah virus infection, where transmission only occurred between animals in direct contact, but not via aerosols or fomites (49). Contact transmission of Nipah virus in Bangladesh is facilitated by healthcare and cultural practices requiring family to care for hospitalized patients and the importance of physical contact with sick relatives and friends (50). 


\section{Concluding remarks}

The Pteropid spp. fruit bat reservoir of Henipaviruses has a wide geographic range that overlaps with some of the most-densely populated areas in the world. Thus, the risk of these viruses causing large-scale epidemics with the potential to spread regionally and possibly globally should not be ignored (51). Important advances in our understanding of Hendra and Nipah virus have been made leading to the development of intervention strategies to block zoonotic transmission. Blocking zoonotic transmission is the most cost-effective and efficient way to prevent large-scale outbreaks in humans. In 2012, a recombinant glycoprotein subunit vaccine against Hendra virus was approved for vaccination of horses (52) with the aim of preventing transmission of Hendra virus from bats to horses and consequently from horses to humans. In Bangladesh, the use of bamboo skirts on date palm sap collection pots to shield them from bats has been proven effective in preventing bats from drinking the sap and thus contaminating the sap with Nipah virus (53) and preventing infection of people drinking date palm sap (54). Despite these promising developments, uptake of the Hendra vaccine is low (4) and the consumption of date palm sap in Bangladesh remains high even in people aware of the risk of acquiring Nipah virus (55). Thus, blocking Henipavirus transmission remains a public health priority. The CEPI initiative to bring a Nipah virus vaccine to licensure (56) is a welcome approach and likely necessary to contain future Henipavirus outbreaks and protect global health.

\section{Acknowledgments}

The authors would like to thank Ryan Kissinger, NIAID/NIH, for designing the figure and Vincent Munster, NIAID/NIH, for helpful discussions. This work was funded by the Intramural Research Program of the NIAID/ NIH.

\section{References}

1. Murray K, Selleck P, Hooper P, Hyatt A, Gould A, Gleeson L, et al. A morbillivirus that caused fatal disease in horses and humans. Science. 1995; 268(5207):94-7. [PubMed: 7701348]

2. Young PL, Halpin K, Selleck PW, Field H, Gravel JL, Kelly MA, et al. Serologic evidence for the presence in Pteropus bats of a paramyxovirus related to equine morbillivirus. Emerg Infect Dis. 1996; 2(3):239-40. [PubMed: 8903239]

3. Halpin K, Young PL, Field HE, Mackenzie JS. Isolation of Hendra virus from pteropid bats: a natural reservoir of Hendra virus. J Gen Virol. 2000; 81(Pt 8):1927-32. [PubMed: 10900029]

4. Field HE. Hendra virus ecology and transmission. Curr Opin Virol. 2016; 16:120-5. [PubMed: 26978066]

5. Kirkland PD, Gabor M, Poe I, Neale K, Chaffey K, Finlaison DS, et al. Hendra Virus Infection in Dog, Australia, 2013. Emerg Infect Dis. 2015; 21(12):2182-5. [PubMed: 26583697]

6. Chua KB, Bellini WJ, Rota PA, Harcourt BH, Tamin A, Lam SK, et al. Nipah virus: a recently emergent deadly paramyxovirus. Science. 2000; 288(5470):1432-5. [PubMed: 10827955]

7. Mohd Nor MN, Gan CH, Ong BL. Nipah virus infection of pigs in peninsular Malaysia. Revue scientifique et technique. 2000; 19(1):160-5. [PubMed: 11189713]

8. Arankalle VA, Bandyopadhyay BT, Ramdasi AY, Jadi R, Patil DR, Rahman M, et al. Genomic characterization of Nipah virus, West Bengal, India. Emerg Infect Dis. 2011; 17(5):907-9. [PubMed: 21529409]

9. Chadha MS, Comer JA, Lowe L, Rota PA, Rollin PE, Bellini WJ, et al. Nipah virus-associated encephalitis outbreak, Siliguri, India. Emerg Infect Dis. 2006; 12(2):235-40. [PubMed: 16494748] 
10. Clayton BA. Nipah virus: transmission of a zoonotic paramyxovirus. Curr Opin Virol. 2017; 22:97-104. [PubMed: 28088124]

11. Hsu VP, Hossain MJ, Parashar UD, Ali MM, Ksiazek TG, Kuzmin I, et al. Nipah virus encephalitis reemergence, Bangladesh. Emerg Infect Dis. 2004; 10(12):2082-7. [PubMed: 15663842]

12**. Ching PK, de los Reyes VC, Sucaldito MN, Tayag E, Columna-Vingno AB, Malbas FF Jr, et al. Outbreak of henipavirus infection, Philippines, 2014. Emerg Infect Dis. 2015; 21(2):328-31. This study describes the findings from a Nipah virus outbreak in the Philippines that was the first time Nipah virus infection was detected in horses, with zoonotic transmission from horses to humans, and subsequent human-to-human transmission. Moreover, it was the first time Nipah virus cases were detected in the Philippines. [PubMed: 25626011]

13. Yob JM, Field H, Rashdi AM, Morrissy C, van der Heide B, Rota P, et al. Nipah virus infection in bats (order Chiroptera) in peninsular Malaysia. Emerg Infect Dis. 2001; 7(3):439-41. [PubMed: 11384522]

14. Marsh GA, de Jong C, Barr JA, Tachedjian M, Smith C, Middleton D, et al. Cedar virus: a novel Henipavirus isolated from Australian bats. PLoS Pathog. 2012; 8(8):e1002836. [PubMed: 22879820]

15. Drexler JF, Corman VM, Gloza-Rausch F, Seebens A, Annan A, Ipsen A, et al. Henipavirus RNA in African bats. PLoS One. 2009; 4(7):e6367. [PubMed: 19636378]

16. Wu Z, Yang L, Yang F, Ren X, Jiang J, Dong J, et al. Novel Henipa-like virus, Mojiang Paramyxovirus, in rats, China, 2012. Emerg Infect Dis. 2014; 20(6):1064-6. [PubMed: 24865545]

17. Hayman DT, Wang LF, Barr J, Baker KS, Suu-Ire R, Broder CC, et al. Antibodies to henipavirus or henipa-like viruses in domestic pigs in ghana, west Africa. PLoS One. 2011; 6(9):e25256. [PubMed: 21966471]

18. Pernet O, Schneider BS, Beaty SM, LeBreton M, Yun TE, Park A, et al. Evidence for henipavirus spillover into human populations in Africa. Nature communications. 2014; 5:5342.

19. De Wit, E., Munster, VJ. Nipah virus emergence, transmission and pathogenesis. In: Shapshak, P.Sinnot, JT.Somboonwit, C., Kuhn, JH., editors. Global Virology I. Springer; 2015. p. 125-46.

20. Enchery F, Horvat B. Understanding the interaction between henipaviruses and their natural host, fruit bats: Paving the way toward control of highly lethal infection in humans. Int Rev Immunol. 2017; 36(2):108-21. [PubMed: 28060559]

21. Halpin K, Hyatt AD, Fogarty R, Middleton D, Bingham J, Epstein JH, et al. Pteropid bats are confirmed as the reservoir hosts of henipaviruses: a comprehensive experimental study of virus transmission. The American journal of tropical medicine and hygiene. 2011; 85(5):946-51. [PubMed: 22049055]

22. Middleton DJ, Morrissy CJ, van der Heide BM, Russell GM, Braun MA, Westbury HA, et al. Experimental Nipah virus infection in pteropid bats (Pteropus poliocephalus). J Comp Pathol. 2007; 136(4):266-72. [PubMed: 17498518]

23. Williamson MM, Hooper PT, Selleck PW, Westbury HA, Slocombe RF. Experimental hendra virus infection in pregnant guinea-pigs and fruit Bats (Pteropus poliocephalus). J Comp Pathol. 2000; 122(2-3):201-7. [PubMed: 10684689]

24. Williamson MM, Hooper PT, Selleck PW, Gleeson LJ, Daniels PW, Westbury HA, et al. Transmission studies of Hendra virus (equine morbillivirus) in fruit bats, horses and cats. Aust Vet J. 1998; 76(12):813-8. [PubMed: 9972433]

25*. Edson D, Field H, McMichael L, Vidgen M, Goldspink L, Broos A, et al. Routes of Hendra Virus Excretion in Naturally-Infected Flying-Foxes: Implications for Viral Transmission and Spillover Risk. PLoS One. 2015; 10(10):e0140670. Thorough study that describes routes of shedding in flying foxes naturally infected with hendra virus and discusses the implication of the findings for Hendra virus transmission. [PubMed: 26469523]

26. Rahman SA, Hassan L, Epstein JH, Mamat ZC, Yatim AM, Hassan SS, et al. Risk Factors for Nipah virus infection among pteropid bats, Peninsular Malaysia. Emerg Infect Dis. 2013; 19(1): 51-60. [PubMed: 23261015]

27. Wacharapluesadee S, Boongird K, Wanghongsa S, Ratanasetyuth N, Supavonwong P, Saengsen D, et al. A longitudinal study of the prevalence of Nipah virus in Pteropus lylei bats in Thailand: 
evidence for seasonal preference in disease transmission. Vector Borne Zoonotic Dis. 2010; 10(2): 183-90. [PubMed: 19402762]

28*. Field H, Jordan D, Edson D, Morris S, Melville D, Parry-Jones K, et al. Spatiotemporal Aspects of Hendra Virus Infection in Pteropid Bats (Flying-Foxes) in Eastern Australia. PLoS One. 2015; 10(12):e0144055. Large-scale study that identifies the role of different flying fox species and environmental factors in Hendra virus prevalence. [PubMed: 26625128]

29*. Goldspink LK, Edson DW, Vidgen ME, Bingham J, Field HE, Smith CS. Natural Hendra Virus Infection in Flying-Foxes - Tissue Tropism and Risk Factors. PLoS One. 2015; 10(6):e0128835. The first study to describe the tissue tropism of Hendra virus in naturally infected fruit bats. [PubMed: 26060997]

30. Selvey LA, Wells RM, McCormack JG, Ansford AJ, Murray K, Rogers RJ, et al. Infection of humans and horses by a newly described morbillivirus. Med J Aust. 1995; 162(12):642-5. [PubMed: 7603375]

31. Marsh GA, Haining J, Hancock TJ, Robinson R, Foord AJ, Barr JA, et al. Experimental infection of horses with Hendra virus/Australia/horse/2008/Redlands. Emerg Infect Dis. 2011; 17(12):22328. [PubMed: 22172152]

32. Hooper PT, Ketterer PJ, Hyatt AD, Russell GM. Lesions of experimental equine morbillivirus pneumonia in horses. Vet Pathol. 1997; 34(4):312-22. [PubMed: 9240840]

33. Field H, Schaaf K, Kung N, Simon C, Waltisbuhl D, Hobert H, et al. Hendra virus outbreak with novel clinical features, Australia. Emerg Infect Dis. 2010; 16(2):338-40. [PubMed: 20113576]

34. Middleton DJ, Westbury HA, Morrissy CJ, van der Heide BM, Russell GM, Braun MA, et al. Experimental Nipah virus infection in pigs and cats. J Comp Pathol. 2002; 126(2-3):124-36. [PubMed: 11945001]

35. Weingartl H, Czub S, Copps J, Berhane Y, Middleton D, Marszal P, et al. Invasion of the central nervous system in a porcine host by nipah virus. J Virol. 2005; 79(12):7528-34. [PubMed: 15919907]

36. Chua KB, Lam SK, Goh KJ, Hooi PS, Ksiazek TG, Kamarulzaman A, et al. The presence of Nipah virus in respiratory secretions and urine of patients during an outbreak of Nipah virus encephalitis in Malaysia. J Infect. 2001; 42(1):40-3. [PubMed: 11243752]

37. Sejvar JJ, Hossain J, Saha SK, Gurley ES, Banu S, Hamadani JD, et al. Long-term neurological and functional outcome in Nipah virus infection. Ann Neurol. 2007; 62(3):235-42. [PubMed: 17696217]

38. Tan CT, Goh KJ, Wong KT, Sarji SA, Chua KB, Chew NK, et al. Relapsed and late-onset Nipah encephalitis. Ann Neurol. 2002; 51(6):703-8. [PubMed: 12112075]

39. Wong KT, Shieh WJ, Kumar S, Norain K, Abdullah W, Guarner J, et al. Nipah virus infection: pathology and pathogenesis of an emerging paramyxoviral zoonosis. Am J Pathol. 2002; 161(6): 2153-67. [PubMed: 12466131]

40. Luby SP, Hossain MJ, Gurley ES, Ahmed BN, Banu S, Khan SU, et al. Recurrent zoonotic transmission of Nipah virus into humans, Bangladesh, 2001-2007. Emerg Infect Dis. 2009; 15(8): 1229-35. [PubMed: 19751584]

41*. Chakraborty A, Sazzad HM, Hossain MJ, Islam MS, Parveen S, Husain M, et al. Evolving epidemiology of Nipah virus infection in Bangladesh: evidence from outbreaks during 2010 2011. Epidemiol Infect. 2016; 144(2):371-80. Epidemiological study from Bangladesh describing transmission of Nipah virus from corpse-to-human. [PubMed: 26122675]

42. Sazzad HM, Hossain MJ, Gurley ES, Ameen KM, Parveen S, Islam MS, et al. Nipah virus infection outbreak with nosocomial and corpse-to-human transmission, Bangladesh. Emerg Infect Dis. 2013; 19(2):210-7. [PubMed: 23347678]

43. Gurley ES, Montgomery JM, Hossain MJ, Islam MR, Molla MA, Shamsuzzaman SM, et al. Risk of nosocomial transmission of Nipah virus in a Bangladesh hospital. Infect Control Hosp Epidemiol. 2007; 28(6):740-2. [PubMed: 17520553]

44. Mounts AW, Kaur H, Parashar UD, Ksiazek TG, Cannon D, Arokiasamy JT, et al. A cohort study of health care workers to assess nosocomial transmissibility of Nipah virus, Malaysia, 1999. J Infect Dis. 2001; 183(5):810-3. [PubMed: 11181159] 
45*. Gurley ES, Montgomery JM, Hossain MJ, Bell M, Azad AK, Islam MR, et al. Person-to-person transmission of Nipah virus in a Bangladeshi community. Emerg Infect Dis. 2007; 13(7):1031-7. This study emphasizes the important role of date palm sap consumption in zoonotic Nipah virus transmission. [PubMed: 18214175]

46. Homaira N, Rahman M, Hossain MJ, Epstein JH, Sultana R, Khan MS, et al. Nipah virus outbreak with person-to-person transmission in a district of Bangladesh, 2007. Epidemiol Infect. 2010; 138(11):1630-6. [PubMed: 20380769]

47. Homaira N, Rahman M, Hossain MJ, Nahar N, Khan R, Podder G, et al. Cluster of Nipah virus infection, Kushtia District, Bangladesh, 2007. PLoS One. 2010; 5(10):e13570. [PubMed: 21042407]

48. ICDDRB. Person-to-person transmission of Nipah virus infection in Bangladesh, 2007. Health and Science Bulletin. 2007; 5(4):1-6.

49. de Wit E, Bushmaker T, Scott D, Feldmann H, Munster VJ. Nipah virus transmission in a hamster model. PLoS neglected tropical diseases. 2011; 5(12):e1432. [PubMed: 22180802]

50. Blum LS, Khan R, Nahar N, Breiman RF. In-depth assessment of an outbreak of Nipah encephalitis with person-to-person transmission in Bangladesh: implications for prevention and control strategies. The American journal of tropical medicine and hygiene. 2009; 80(1):96-102. [PubMed: 19141846]

51. Organization WH. WHO publishes list of top emerging diseases likely to cause major epidemics. 2015

52. Broder CC, Weir DL, Reid PA. Hendra virus and Nipah virus animal vaccines. Vaccine. 2016; 34(30):3525-34. [PubMed: 27154393]

53. Khan SU, Gurley ES, Hossain MJ, Nahar N, Sharker MA, Luby SP. A randomized controlled trial of interventions to impede date palm sap contamination by bats to prevent nipah virus transmission in Bangladesh. PLoS One. 2012; 7(8):e42689. [PubMed: 22905160]

54. Gurley ES, Hegde ST, Hossain K, Sazzad HMS, Hossain MJ, Rahman M, et al. Convergence of Humans, Bats, Trees, and Culture in Nipah Virus Transmission, Bangladesh. Emerg Infect Dis. 2017; 23(9):1446-53. [PubMed: 28820130]

55*. Nahar N, Paul RC, Sultana R, Gurley ES, Garcia F, Abedin J, et al. Raw Sap Consumption Habits and Its Association with Knowledge of Nipah Virus in Two Endemic Districts in Bangladesh. PLoS One. 2015; 10(11):e0142292. Interesting study that highlights the difficulty in preventing zoonotic transmission of Nipah virus in Bangladesh through behavioral changes involving drinking of raw date palm sap. [PubMed: 26551202]

56. Butler D. Epic project to stockpile vaccines. Nature. 2017; 541:444-5. [PubMed: 28128262] 


\section{Highlights}

- Hendra virus and Nipah virus are known to be transmitted within several host species: fruit bats, horses, pigs and humans

- The main route of virus shedding is urine in bats, but respiratory secretions in horses, pigs and humans

- Despite different routes of virus shedding, close contact is required for transmission in all host species 


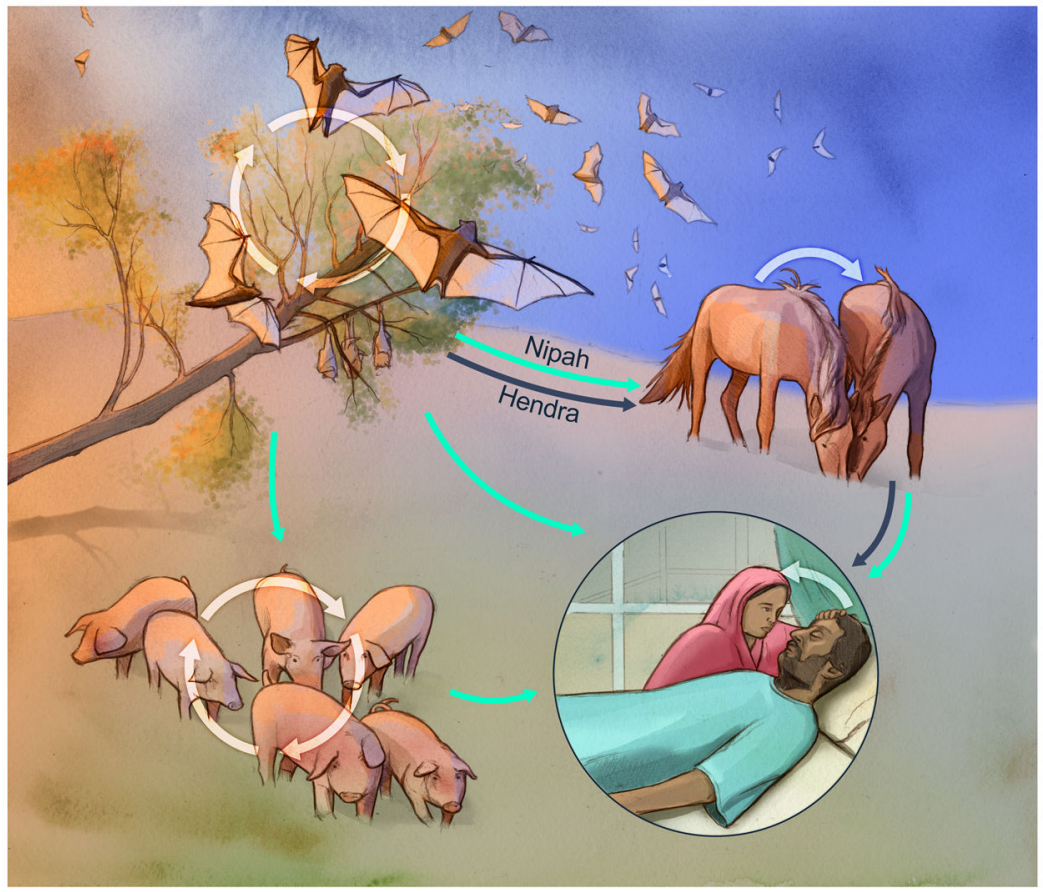

Figure. Transmission cycles of Hendra and Nipah virus in their respective hosts

Pteropid spp. bats are the natural reservoir of Hendra and Nipah virus. Bats mainly shed virus via urine and the virus is transmitted through close contact between bats in roosts. From the natural reservoir, viruses are spread to pigs and horses who function as amplifying hosts. Horses shed virus in respiratory secretions and urine; transmission of virus to naïve horses requires close contact. Pigs mainly shed virus via their nose and transmission to naïve animals is rapid and efficient between pigs in close contact. Humans are infected through close contact with the intermediate hosts, or directly via consumption of date palm sap contaminated with bat urine during collection. Nipah virus disease patients transmit the virus via contact of caretakers with respiratory secretions. Blue arrows indicate transmission routes of Hendra virus; green arrows indicate transmission routes of Nipah virus. 